\title{
Effect of some light sources on broiler chickens performance under Assiut conditions, Egypt
}

\author{
Ahmed S. F. ${ }^{*}{ }^{a}$, Fahmy S. ${ }^{a}$, Afifi O. S. ${ }^{b}$, Madian A. H. ${ }^{a}$ \\ ${ }^{a}$ Department of Animal Production, Faculty of Agriculture, Al-Azhar University (Assiut Branch), Assiut, Egypt \\ ${ }^{b}$ Poultry Production Department, Faculty of Agriculture, Assiut University, Assiut, Egypt
}

\begin{abstract}
This study aimed to compare the effect of three different light sources on the growth performance and carcass quality of broiler chickens. Birds were wing banded, individually weighed and randomly assigned to three experimental groups, each including three equal replicates each of 15 chicks. Birds in groups 1, 2 and 3 were exposed to light emitted from incandescent (INC), saving (SAV) and Light Emitting Diodes (LED) lamps, respectively. The studied traits included (BW), (BWG), mortality rate, (FC), (FCR), carcass traits and the economic efficiency. The average BW of broilers in (T2) was significantly higher $(\mathrm{P} \leq 0.05)$ at $2,4,5$ and 6 weeks than those of birds in (T1) and the (control). The best average of the all experimental period FCR7 g (1.71) was recorded in $\mathrm{T} 2$ improving significantly $(\mathrm{P} \leq 0.05)$ than those 1.78 and $1.83 \mathrm{~g}$ of $(\mathrm{T} 1)$ and the (control), respectively. In the same group, (T2) significantly $(\mathrm{P} \leq 0.05)$ increased the percentages of Carcass, Gizzard, Liver, Heart, Spleen, Giblets and dressing than those of the birds in (T1) and the control. Economically, the use of (LED) as lighting source decreased the costs of the lighting program by about $82.87 \%$ compared with the (INC) control. The results of this study indicated that the using of (LED) is highly recommended in the broiler production to achieve the best possible profit, especially with the progressive increase in the prices of feed ingredients and power cost.
\end{abstract}

Keywords: broiler, light source, led lamps, growth performance, carcass traits, economic efficiency. 


\section{Introduction}

Biologically, light is one of the major microclimate factors that affect avian production and reproduction (Hamdy, 2014). It plays a pivotal role regarding sight, stimulating the internal organs and initiating the hormonal release (Blair et al., 2000). The chicken eye is superior to the livestock eyes, since it can discriminate the light color (Prescott and Wathes, 1999). In addition, there are extra-retinal photoreceptors in the hypothalamus or in the brain, which are sensitive to the varied wavelengths and the transduction of photo stimulations (Lewis et al., 2003). The light allows for the establishment of circadian rhythms and synchronization of various essential physiological functions including body temperature, metabolism and secretion of hormones that influence growth, maturation and reproduction (Olanrewaju et al., 2016). The lighting program for a particular brooder house varies depending on the type of poultry (layer hen, breeding stock vs. broiler, turkey, quail) and even the specific genetic strain of poultry (Lien et al., 2007; 2008). North and Bell (1990) stated that it is important to choose the most adequate and economic lighting source, among incandescent, fluorescent, saving, metal halide and high-pressure sodium lamps, for raising growing chicks, laying hens and breeder stocks. Therefore, most of the recent researches have focused on restricting light regimens to improve productivity of broiler chickens because the physical activity is very low during darkness and energy expenditure of activity is considerable (Bertolucci and Foa, 2004; Wyse and Hazlerigg, 2009). Applying adequate lighting regimen and using the most economical light source were found to improve not only the poultry production but also the carcass quality (EL-Hammady et al., 2014; Lien et al., 2007; 2008). Due to the enormous shortage of energy sources and their progressive increasing costs all over the world and especially in Egypt, it became essential to achieve the efficient lighting for the least costs by applying the efficient manipulations (Ahmed et al., 2015; Hamdy, 2014). Recently, researchers recommended use of the saving lamps, which are characterized by the longer life and less power costs than the other types (El-Hammady et al., 2014; Farghly et al., 2015a). The available information in the literature regarding the effect of light sources on the poultry performance is very limited. Therefore, the present study aimed to evaluate the impact of light produced by incandescent, saving and LED lamps on the growth performance, carcass quality, and the economic efficiency of broiler chickens.

\section{Materials and methods}

The present study was performed at the Experimental Poultry Farm, Department of Animal and Poultry production, Faculty of Agriculture of Al-Azhar University (Assiut Branch), Assiut, Egypt during the period from March 15 to April 26,2017 . It aimed to compare among the impact of light produced by incandescent (INC), saving (SAV) and Light Emitting Diodes (LED) lamps on the growth performance, carcass traits, and economical efficiency of broiler chickens during the experiment (42 days).

\subsection{Housing and experimental design}

One hundred and thirty-five, one day-old, 
Ross broiler chickens were used. Chicks were wing banded, individually weighed and randomly assigned to three experimental groups, each including three equal replicates each of 15 chicks. All experimental chicks were housed in three separated floor pens which provided with suitable number of fans to maintain adequate temperature and good ventilation in open house under adequate and similar managerial and hygienic conditions. The indoor temperature was $32{ }^{\circ} \mathrm{C}$ during the first day, then reduced by about $2{ }^{\circ} \mathrm{C}$ every week to reach $24^{\circ} \mathrm{C}$ at the fourth week of age and then lasted to the end of the experiment. The relative humidity (RH \%) ranged from 55-60\% up to the end of the experiment. The temperature values and the relative humidity percentages were daily recorded by using a thermo-hygrograph and the temperature humidity indices-THI values were calculated all over the experimental periods. Chicks in the first experimental group (Control), were exposed to light produced from 60 watt incandescent lamps, while the second and third groups (Treatments 1 and 2) were subjected to light emitted from saving and Light Emitting Diodes (LED) lamps having the efficiency of 26 and 9 watt, respectively. All lighting sources were hanged at 2 meters height from the ground and adjusted to emit light with intensity of 4045 Lux during the first three days, thereafter, decreased gradually to reach 15-20 Lux at the bottom level of the three trials till the end of the experiment.

Table (1): Composition and calculated analysis of experimental diets.

\begin{tabular}{lcc}
\hline Ingredients & Starter diet & Grower diet \\
\hline Yellow corn & 62.00 & 67.00 \\
Soybean meal $(44 \% \mathrm{CP})$ & 27.80 & 20.00 \\
Corn gluten meal $(60 \% \mathrm{CP})$ & 6.32 & 8.30 \\
Veg. Oil & -- & - \\
Di-Calcium Phosphate & 1.90 & 1.93 \\
Limestone & 1.29 & 1.34 \\
Salt $(\mathrm{NaCl})$ & 0.10 & 0.10 \\
DL-Methionine & 0.14 & 0.23 \\
L-Lysine & 0.19 & 0.48 \\
Vit. \& Min. Premix ${ }^{1}$ & 0.25 & 0.25 \\
Filler (sand) & 0.01 & 0.37 \\
Total & 99.78 & 100.00 \\
\hline & Calculated analysis $(\%)$ & 3152 \\
\hline ME $(\mathrm{kcal} / \mathrm{kg})$ & 3000 & 21 \\
Crude Protein & 23 & 1.00 \\
Calcium & 1.00 & 0.50 \\
Available Phosphorus & 0.50 & 1.28 \\
Lysine & 1.16 & 0.59 \\
Methionine & 0.52 & 0.15 \\
Choline $(m g / k g)$ & 0.13 & \\
\hline
\end{tabular}

${ }^{1}$ Premix provides by kg: Vit A, $5500 \mathrm{IU}$; Vit E, $11 \mathrm{IU}$; Vit D3, $1100 \mathrm{IU}$; riboflavin, $4.4 \mathrm{mg}$; Ca pantothenate, $12 \mathrm{mg}$; nicotinic acid, $44 \mathrm{mg}$; choline chloride, $191 \mathrm{mg}$; vitamin B12, $12.1 \mathrm{ug}$; vitamin B6, $2.2 \mathrm{mg}$; thiamine (as thiamine mononitrate), $2.2 \mathrm{mg}$; folic acid, $0.55 \mathrm{mg}$ and d- biotin, $0.11 \mathrm{mg}$. Trace mineral (mg / kg diet): $\mathrm{Mn}, 60 ; \mathrm{Zn}, 50 ; \mathrm{Fe}, 30 ; \mathrm{Cu}, 5$ and $\mathrm{Se}, 0.3$.

Feed and water were available all the time during the whole experiment. Birds were fed on a starter ration, during the first 10 days of age and thereafter on a grower 
ration till the end of the experiment (Table 1). They were weekly weighed to the nearest gram on individual basis.

\subsection{Studied criteria}

\subsubsection{Body weight and body weight gain}

Birds per each replicate were individually weighed every week, while the daily average body weight gain was weekly calculated, as the difference between the final and initial body weight, taking in consideration the number of survived chicks.

\subsubsection{Feed consumption and conversion ratio}

The average feed consumption per replicate was weekly calculated as the difference between the offered and remained amounts of feed, divided by the number of survived chicks. The average feed conversion ratio ( $\mathrm{g}$ feed/g gain) per replicate was calculated by dividing the total feed consumed on the total body weight gain of the survived chicks throughout each one successive week.

\subsubsection{Carcass traits}

At the end of the experiment (42 days of age) 9 chickens, per each group i.e. (three birds per replicate), which have been fasted for 8 hours, were randomly chosen and slaughtered. After complete bleeding, they were scalded, plucked, thereafter the edible organs (heart, liver, empty gizzard), spleen and the abdominal fat were gently removed, weighed and estimated as percentages of the live body weight. The dressing percentage was estimated by dividing the weights of the carcass and giblets on the pre-slaughter live body weight of birds.

\subsubsection{Mortality rate}

The number of dead birds / replicate / groups were daily recorded, and the total mortality percentages were calculated.

\subsubsection{The economic efficiency}

It was estimated according to the following basis:

1. The lighting costs (LC) include the values of power cost $(\mathrm{kw} / \mathrm{LE})$. (A) = lighting hours $=($ Experimental period $\mathrm{X}$ light/day 42 days * $24 \mathrm{~L} \mathrm{h/day)} \mathrm{and}$ the lamps depreciation, (B) = Price $/ \mathrm{Kw} / \mathrm{LE}$ (Depreciation = lighting $\mathrm{h} / \mathrm{Life}$ span/h, price of lamp /LE) estimated by dividing the number of lighting hours, on the life span of the lamps, which amounted 1000, 8000 and 20000 light hours for the incandescent, saving and LED lamps, respectively.

2. The price of $1 \mathrm{kw}$ amounted 0.94 LE.

3. The price of the $60 \mathrm{w}$ incandescent lamps amounted 5.0 LE versus 15.0 and 45.0 LE for the 26w saving lamps and 9w LED lamps, respectively.

4. Total Costs $=\mathrm{A}+\mathrm{B} / \mathrm{LE}$ showed in Table (7) (Ahmed et al., 2015; Hamdy, 2014).

\subsubsection{Statistical analysis}

The obtained data were statistically analyzed by ANOVA using the General 
Linear Model (GLM) Procedure of SAS software (SAS institute, version 9.2, 2009) Duncan's multiple range test (Duncan, 1955) was used to detect the differences among means of different groups.

\section{Results and Discussion}

\subsection{Body weight and body weight gain}

The results of body weight (BW) and body weight gain (BWG) as affected by the three light sources are presented in Tables (2 and 3). Birds exposed to light produced from 9w LED lamps (T2) had significantly $(\mathrm{P} \leq 0.05)$ higher $\mathrm{BW}$ at 2,4 , 5 and 6 weeks than those of birds subjected to light emitted from the incandescent lamps (control) and the saving lamps (T1). Meantime birds exposed to light produced from 9w LED lamps (T2) had increased numerically BW at the third week than those of the other two groups. Similarly, BWG at the periods of BWG2 (7 - 14d), BWG4 (21 $28 \mathrm{~d})$ and the all experimental period BWG7 all $(0-42 \mathrm{~d})$ increased significantly $(\mathrm{P} \leq 0.05)$ in birds exposed to light produced from 9w LED than those on the other sources. On the other hand insignificantly $(\mathrm{P} \leq 0.05)$ improved was observed on BWG at the periods BWG1 $(0-7 \mathrm{~d})$, BWG3 (14 - 21d), BWG5 (28 35d) and BWG6 (35 - 42d) on broiler exposed to light produced from 9w LED lamps than those of the (control) and (T1).

Table (2): Averages \pm SE of body weight (g) of Ross broiler chickens as affected by three light sources.

\begin{tabular}{|c|c|c|c|}
\hline \multirow{3}{*}{ Age week } & \multicolumn{3}{|c|}{ Experimental groups } \\
\hline & (Control) & (T1) & (T2) \\
\hline & Incandescent Lamp & Saving lamp & LED lamp \\
\hline BW1 (one day) & $59.64 \pm 0.45$ & $59.47 \pm 0.45$ & $59.65 \pm 0.45$ \\
\hline BW2 ( $1^{\text {st }}$ week $)$ & $162.23 \pm 1.107$ & $162.48 \pm 1.107$ & $163.50 \pm 1.107$ \\
\hline BW3 ( $2^{\text {nd }}$ week) & $395.10^{\mathrm{b}} \pm 1.99$ & $396.10^{\mathrm{b}} \pm 1.99$ & $402.20^{\mathrm{a}} \pm 1.99$ \\
\hline BW4 (3 $3^{\text {rd }}$ week) & $703.69 \pm 7.21$ & $710.49 \pm 7.21$ & $724.59 \pm 7.21$ \\
\hline BW5 (4 ${ }^{\text {th }}$ week $)$ & $1047.89^{\mathrm{b}} \pm 7.92$ & $1056.95^{\mathrm{b}} \pm 7.92$ & $1083.16^{\mathrm{a}} \pm 7.92$ \\
\hline BW6 (5 $5^{\text {th }}$ week $)$ & $1414.51^{\mathrm{b}} \pm 7.74$ & $1422.98^{b} \pm 7.74$ & $1457.35^{\mathrm{a}} \pm 7.74$ \\
\hline BW7 (6 $6^{\text {th }}$ week $)$ & $1897.03^{\mathrm{b}} \pm 16.44$ & $1912.89^{\mathrm{ab}} \pm 16.44$ & $1955.60^{\mathrm{a}} \pm 16.44$ \\
\hline
\end{tabular}

$\overline{a, b, c}$ Means $( \pm \mathrm{SE})$ in the same row with different superscripts are significantly different $(\mathrm{P} \leq 0.05)$. $\mathrm{BW}=\mathrm{body}$, weight (g), L.S= light source.

The obtained results agree with Behnke and Beyer (2006) and Angélica Mendes et al. (2013) who attributed that the chickens raised under white LED bulbs had better production performance (BW and BWG) than did chickens raised under CFL and INC bulbs. The significant increase in BW and BWG for broiler reared under light emitted from LED lamps may be as a result of decreased stress found in the LED treatments, which in turn, decreasing in "waste energy" may increase the amount of energy put towards muscle growth, 
thereby improving conversion of feed who found that the body weight, were into muscle (Huth and Archer, 2015; highest at the birds reared under warmRiber, 2015). Similar results, were white light emitted from LED lamps obtained by Hossein and Zaghari (2016) compared to the incandescent treatment.

Table (3): Averages \pm SE of weekly body weight gain (g) of Ross broiler chickens as affected by three light sources.

\begin{tabular}{lccc}
\hline & & Experimental groups & \\
\cline { 2 - 4 } Age week & $\begin{array}{c}\text { (Control) } \\
\text { Incandescent Lamp }\end{array}$ & $\begin{array}{c}(\mathrm{T} 1) \\
\text { Saving lamp }\end{array}$ & $\begin{array}{c}(\mathrm{T} 2) \\
\text { LED lamp }\end{array}$ \\
\hline BWG1 $(0-7 \mathrm{~d})$ & $102.59 \pm 1.09$ & $103.01 \pm 1.09$ & $103.85 \pm 1.09$ \\
BWG2 $(7-14 \mathrm{~d})$ & $232.86^{\mathrm{b}} \pm 1.53$ & $233.62^{\mathrm{b}} \pm 1.53$ & $238.52^{\mathrm{a}} \pm 1.53$ \\
BWG3 $(14-21 \mathrm{~d})$ & $308.20 \pm 6.55$ & $314.01 \pm 6.55$ & $321.62 \pm 6.55$ \\
BWG4 $(21-28 \mathrm{~d})$ & $342.59^{\mathrm{b}} \pm 7.35$ & $345.15^{\mathrm{b}} \pm 7.35$ & $358.57^{\mathrm{a}} \pm 7.22$ \\
BWG5 $(28-35 \mathrm{~d})$ & $366.62 \pm 5.03$ & $366.02 \pm 5.03$ & $373.30 \pm 5.03$ \\
BWG6 $(35-42 \mathrm{~d})$ & $483.30 \pm 11.35$ & $489.91 \pm 11.35$ & $498.28 \pm 11.35$ \\
Total BWG7 all $(0-42 \mathrm{~d})$ & $1837.36^{\mathrm{b}} \pm 16.44$ & $1853.37^{\mathrm{ab}} \pm 16.14$ & $1895.99^{\mathrm{a}} \pm 16.14$ \\
\hline
\end{tabular}

a,b,c Means $( \pm \mathrm{SE})$ in the same row with different superscripts are significantly different $(\mathrm{P} \leq 0.05)$. $\mathrm{BWG}=$ body weight gain $(\mathrm{g}), \mathrm{L} . \mathrm{S}=$ light source.

Also, Olanrewaju et al. (2016) and Mohamed et al. (2017) reported that the overall growth and production parameters of $\mathrm{BW}$ and $\mathrm{BWG}$ which examined in birds exposed to light produced from incandescent bulb group were statistically lower than those of the birds subjected to light emitted from the blue, green, and Cool-LED bulb. Contradictory, BW and BWG were not exhibit statistically differences due to light sources (Ahmed et al., 2015; Cao et al., 2008; Kristensen et al., 2006).

\subsection{Feed consumption and feed conversion ratio}

The results presented in Tables $(4,5)$, showed significant differences in the weekly feed consumption of the birds exposed to light emitted from three light sources. The averages of weekly feed consumption (FC) at the periods of $\mathrm{FC} 1$ $(0-7 d)$, FC3 $(14-21 d)$ and FC5 (28 $35 \mathrm{~d}$ ) of age for birds exposed to light produced from 9w LED lamps (T2) decreased significantly $(\mathrm{P} \leq 0.05)$ than those of the birds subjected to light emitted from the saving lamps (T1) and the incandescent lamps (control). During the periods of FC2 $(7-14 d)$, FC4 (21 28d), FC6 (35 - 42d) and the all experimental period FC7 $(0-42 d)$ of age, the averages of $\mathrm{FC}$ for birds exposed to light produced from $9 \mathrm{w}$ LED lamps (T2) decreased significantly $(\mathrm{P} \leq 0.05)$ than those of the birds exposed to light produced from the saving lamps (T1). However, there were significantly decrease in FC of broilers subjected to light produced from the saving lamps (T1) than those of the birds exposed to 
light produced from the incandescent lamps (control). Concerning the feed conversion ratio (FCRg), it tended the trend of $(\mathrm{FC})$. During the periods of FCR2 $(7-14 d)$ and whole experiment period FCR7 $(0-42 d)$ the averages of feed conversion ratio (FCR) amounted
(1.13) and (1.71) by using the LED lamps, improved highly significant $(\mathrm{P} \leq 0.01)$ than that $(1.22)$ and $(1.83)$ of the incandescent lamps (control), but significantly $(\mathrm{P} \leq 0.05)$ than that (1.18) and (1.78) of the saving lamps (T1), respectively.

Table (4): Averages \pm SE of feed consumption ( $\mathrm{g}$ Feed/bird/period) of Ross broiler chickens as affected by three light sources.

\begin{tabular}{lccc}
\hline & \multicolumn{3}{c}{ Experimental groups } \\
\cline { 2 - 4 } Age days & $\begin{array}{c}\text { (Control) } \\
\text { Incandescent Lamp }\end{array}$ & $\begin{array}{c}(\mathrm{T} 1) \\
\text { Saving lamp }\end{array}$ & $\begin{array}{c}\text { (T2) } \\
\text { LED lamp }\end{array}$ \\
\hline FC1 $(0-7 \mathrm{~d})$ & $113.93^{\mathrm{a}} \pm 0.15$ & $113.53^{\mathrm{a}} \pm 0.15$ & $111.90^{\mathrm{b}} \pm 0.15$ \\
FC2 $(7-14 \mathrm{~d})$ & $284.30^{\mathrm{a}} \pm 0.19$ & $274.70^{\mathrm{b}} \pm 0.19$ & $269.53^{\mathrm{c}} \pm 0.19$ \\
FC3 $(14-21 \mathrm{~d})$ & $504.46^{\mathrm{a}} \pm 0.35$ & $505.36^{\mathrm{a}} \pm 0.35$ & $500.54^{\mathrm{b}} \pm 0.35$ \\
FC4 $(21-28 \mathrm{~d})$ & $631.83^{\mathrm{a}} \pm 0.73$ & $627.68^{\mathrm{b}} \pm 0.72$ & $621.34^{\mathrm{c}} \pm 0.72$ \\
FC5 $(28-35 \mathrm{~d})$ & $717.30^{\mathrm{a}} \pm 0.39$ & $717.61^{\mathrm{a}} \pm 0.40$ & $713.62^{\mathrm{b}} \pm 0.40$ \\
FC6 $(35-42 \mathrm{~d})$ & $1092.37^{\mathrm{a}} \pm 0.58$ & $1036.53^{\mathrm{b}} \pm 0.57$ & $1013.76^{\mathrm{c}} \pm 0.57$ \\
Total FCR7 all $(0-42 \mathrm{~d})$ & $3344.26^{\mathrm{a}} \pm 0.91$ & $3275.58^{\mathrm{b}} \pm 0.90$ & $3230.85^{\mathrm{c}} \pm 0.90$ \\
\hline
\end{tabular}

a,b,c Means $( \pm$ SE) in the same row with different superscripts are significantly different $(\mathrm{P} \leq 0.05) . \mathrm{FC}=$ Feed consumption $\mathrm{g}$ feed $/ \mathrm{bird} /$ week, $\mathrm{L} . \mathrm{S}=$ light source.

Table (5): Averages \pm SE of feed conversion (g Feed/g gain/week) of Ross broiler chickens as affected by three light sources.

\begin{tabular}{lccc}
\hline & \multicolumn{3}{c}{ E.S } \\
\cline { 2 - 4 } Age days & $\begin{array}{c}\text { (Control) } \\
\text { Incandescent Lamp }\end{array}$ & $\begin{array}{c}(\mathrm{T} 1) \\
\text { Saving lamp }\end{array}$ & $\begin{array}{c}\text { (T2) } \\
\text { LED lamp }\end{array}$ \\
\hline FCR1 $(0-7 \mathrm{~d})$ & $1.12 \pm 0.01$ & $1.11 \pm 0.01$ & $1.08 \pm 0.01$ \\
FCR2 $(7-14 \mathrm{~d})$ & $1.22^{\mathrm{a}} \pm 0.01$ & $1.18^{\mathrm{b}} \pm 0.01$ & $1.13^{\mathrm{c}} \pm 0.01$ \\
FCR3 $(14-21 \mathrm{~d})$ & $1.66 \pm 0.04$ & $1.62 \pm 0.04$ & $1.58 \pm 0.04$ \\
FCR4 $(21-28 \mathrm{~d})$ & $1.86 \pm 0.04$ & $1.83 \pm 0.04$ & $1.77 \pm 0.04$ \\
FCR5 $(28-35 \mathrm{~d})$ & $1.97 \pm 0.03$ & $1.97 \pm 0.03$ & $1.93 \pm 0.03$ \\
FCR6 $(35-42 \mathrm{~d})$ & $2.29^{\mathrm{a}} \pm 0.05$ & $2.14^{\mathrm{b}} \pm 0.05$ & $2.08^{\mathrm{b}} \pm 0.05$ \\
Total FCR7 all $(0-42 \mathrm{~d})$ & $1.83^{\mathrm{a}} \pm 0.02$ & $1.78^{\mathrm{b}} \pm 0.02$ & $1.71^{\mathrm{c}} \pm 0.02$ \\
\hline
\end{tabular}

a,b,c Means $( \pm \mathrm{SE})$ in the same row with different superscripts are significantly different $(\mathrm{P} \leq 0.05)$. FCR $=$ Feed conversion ratio $\mathrm{g}$ feed/g gain /Week, L.S= light source.

While the birds exposed to light emitted from the LED lamps (T2) and the saving lamps (T1) improved significantly $(\mathrm{P} \leq 0.05)$ than that the birds subjected to light produced from the incandescent lamps (control). From FCR1 $(0-7 d)$, FCR3 (14 - 21d), FCR4 $(21-28 d)$ and
FCR5 (28 - 35d), days of age, the weekly average (FCR) recorded the best value of the birds exposed to light emitted from the LED lamps (T2) improving non-significantly than those of the birds subjected to light emitted from the saving lamps (T1) and the 
incandescent lamps (control), descending order, respectively. The previous results agree with those of Rozenboim et al. (2004), Cao et al. (2008) and Angélica Mendes et al. (2013) who found that the chickens exposed to light emitted from white LED lamps had the least FC and the better FCR than did chickens reared under the other light sources. Moreover, significant differences in FC and FCR of birds exposed to light emitted from different light sources were observed by Riber (2015), Huth and Archer (2015) and Olanrewaju et al. (2015). Also, Hossein and Zaghari (2016) reported that the FCR was lowest at birds reared under light emitted from warm-white light LED lamps compared to the reared under the light emitted from the incandescent lamps. The improved feed efficiency (FC and FCR) could be attributed to calming effect of white dim light where, birds become less active and less stressful. Olanrewaju et al. (2016) suggested that the modern commercial poultry facilities should be using dim light to optimize feed conversion and reduce energy utilization. Mohamed et al. (2017) indicated that the lowest FCR was observed in birds exposed to light produced from LED light than those of the other treatments. In contrast, Mendes et al. (2013) found that the FC and FCR for broilers reared under different light sources remain unaffected.

\subsection{Carcass traits}

The impact of light source on the Ross broiler carcass traits are presented in Table (6). It revealed that the light produced by $9 \mathrm{w}$ LED lamps (T2) significantly $(\mathrm{P} \leq 0.05)$ increased the percentages of carcass, Gizzard, Liver, Heart, Spleen, Giblets and dressing than those of the birds exposed to light emitted from the 26 watt saving lamps (T1) and the $60 \mathrm{w}$ incandescent lamps (control). These results agree with those obtained by Simsek et al. (2009), Hamdy (2014) and El-Hammady et al. (2014), who found that the carcass characteristics were improved for broiler chickens reared under different light sources. The beneficial light source as LED lamps stimulates melatonin the cellular and humeral immune responses and improve the carcass traits in broiler Japanese quail (Moore and Siopes, 2003). The significant increase in carcass parameters, dressing and Giblets percentages by using the LED lamps in this study may be because of the acidbase status of poultry is challenged daily by environmental factors such as light, temperature, humidity and air quality, as well as by other factors including nutrition that influence respiratory and metabolic activities. The principal organ systems used in acid-base homeostasis in birds are the lungs and kidneys, supported by the gastrointestinal tract (Long, 1982; Xie et al., 2008). In addition to the green LED lamps illumination could improve the antioxidative capacity and secretion of melatonin to promote B lymphocyte proliferation of bursa of fabricius in 
young broilers (Li et al., 2015). other hand, Deep et al. (2010), Farghly Moreover, Riber (2015), Huth and and Abdel-nabi (2011), Farghly et al. Archer (2015), Hossein and Zaghari (2015b), Ahmed et al. (2015) and (2016) and Olanrewaju et al. (2016) found that the carcass traits, giblets and immune organs improved in birds reared under light emitted from LED lamps compared to the other sources. On the Mohamed et al. (2017) who reported that most of the carcass characteristics for poultry species (broilers, Dandarawi chickens and Japanese quail) were not affected by various light sources.

Table (6): Averages $\pm \mathrm{SE}$ of some carcass traits and mortality rate in broiler chickens affected by three light sources.

\begin{tabular}{|c|c|c|c|}
\hline \multirow[b]{2}{*}{ Traits } & \multicolumn{3}{|c|}{ Experimental groups } \\
\hline & $\begin{array}{c}\text { (Control) } \\
\text { Incandescent Lamp }\end{array}$ & $\begin{array}{c}(\mathrm{T} 1) \\
\text { Saving lamp }\end{array}$ & $\begin{array}{c}\text { (T2) } \\
\text { LED lamp }\end{array}$ \\
\hline Live Wight & $1972.50^{\mathrm{b}} \pm 23.39$ & $2017.07^{\mathrm{ab}} \pm 23.39$ & $2083.58^{\mathrm{a}} \pm 23.39$ \\
\hline Carcass \% & $68.85^{\mathrm{b}} \pm 0.40$ & $70.09^{\mathrm{ab}} \pm 0.04$ & $70.45^{\mathrm{a}} \pm 0.04$ \\
\hline Gizzard\% & $1.99^{b} \pm 0.04$ & $2.02^{\mathrm{b}} \pm 0.04$ & $2.23^{\mathrm{a}} \pm 0.04$ \\
\hline Liver \% & $2.20^{\mathrm{b}} \pm 0.07$ & $2.37^{\mathrm{ab}} \pm 0.07$ & $2.58^{\mathrm{a}} \pm 0.07$ \\
\hline Heart $\%$ & $0.59^{\mathrm{b}} \pm 0.02$ & $0.62^{\mathrm{b}} \pm 0.02$ & $0.76^{\mathrm{a}} \pm 0.02$ \\
\hline Spleen $\%$ & $0.16^{\mathrm{b}} \pm 0.003$ & $0.17^{\mathrm{b}} \pm 0.003$ & $0.19^{\mathrm{a}} \pm 0.003$ \\
\hline Giblets \% & $4.78^{\mathrm{b}} \pm 0.08$ & $5.03^{b} \pm 0.08$ & $5.57^{\mathrm{a}} \pm 0.08$ \\
\hline Dressing \% & $73.63^{\mathrm{b}} \pm 0.38$ & $75.11^{\mathrm{a}} \pm 0.38$ & $76.04^{\mathrm{a}} \pm 0.38$ \\
\hline Mortality rate $\%$ & $6.67 \pm 1.28$ & $6.67 \pm 1.28$ & $4.44 \pm 1.28$ \\
\hline
\end{tabular}

a,b,c Means $( \pm$ SE) in the same row with different superscripts are significantly different $(\mathrm{P} \leq 0.05)$. L.S $=$ light source

\subsection{Mortality rate}

The results of mortality rate were listed in (Table 6), showed no significant differences among the three light sources. However, birds exposed to light produced by LED lamps had decreased numerically mortality rate than those of the other sources. These results are in agreement with those of Kristensen et al. (2006), Huth and Archer (2015), Olanrewaju et al. (2015) and Hossein and Zaghari (2016) who found that exposing broilers to light produced from (INC, SAV and LED) had no significant effect on the mortality rate during the experimental period (42 days).

\subsection{The economic efficiency}

From data presented in Table (7), it could be noticed that the LED lamps minimized the lighting costs than that of the incandescent lamps (control) by about $82.87 \%$, while the decrease amounted only $57.21 \%$ by using the saving lamps. These results agree with those of Hakan and Ali (2005) found that monochromatic illumination could be applied successfully in broiler breeding and LED lamps are highly attractive alternative for the poultry house lighting. Furthermore, LED bulbs have been studied for use in modern poultry husbandry without any negative impact on broiler growth and 
production performances (Cao et al., 2008; Halevy et al., 1998; Rozenboim et al., 1999). Moreover, the achieved reduction of the power cost by using LED lamps in illuminating the breeding and production farms of broiler chickens dos not agree with those of Hamdy (2014) and El-Hammady et al. (2014) who, reported that the use of a 26-watt saving lamps decreased the lighting costs by about $56.7 \%$ as compared with the incandescent lamp.

Table (7): The economic efficiency of the tested light sources.

\begin{tabular}{|c|c|c|c|c|}
\hline Light Source & $\begin{array}{c}{ }^{(\mathrm{A})} \text { Power costs LE }=\text { Lighting } \\
\text { hours*lamp Power/wh *Price /Kw }\end{array}$ & (B) Value of lamp depreciation & $(\mathrm{A}+\mathrm{B})$ & Relative (\%) \\
\hline Incandescent, $60 \mathrm{~W}$ & $\begin{array}{c}1008 \mathrm{~h} * 60 \mathrm{w}=60.48 \mathrm{kw} \\
* 0.95 \mathrm{LE}=57.46 \mathrm{LE}\end{array}$ & $(1008 / 1000)^{*} 6.00=6.04 \mathrm{LE}$ & $63.50 \mathrm{LE}$ & $100 \%$ \\
\hline Saving, 26W & $\begin{array}{c}1008 \mathrm{~h} * 26 \mathrm{w}=26.21 \mathrm{kw} \\
* 0.95 \mathrm{LE}=24.90 \mathrm{LE}\end{array}$ & $(1008 / 8000) * 18.00=2.27 \mathrm{LE}$ & 27.17 LE & $\begin{array}{l}42.79 \% \\
-57.21 \% \\
\end{array}$ \\
\hline LED, 9w & $\begin{array}{l}1008 \mathrm{~h} * 9 \mathrm{w}=9.07 \mathrm{kw} \\
* 0.95 \mathrm{LE}=8.62 \mathrm{LE}\end{array}$ & $(1008 / 20000) * 45.00=2.26 \mathrm{LE}$ & $10.88 \mathrm{LE}$ & $\begin{array}{c}17.13 \% \\
-82.87 \%\end{array}$ \\
\hline
\end{tabular}

(A) lighting hours $=$ Experimental period $\times$ light/day 42 days $* 24 \mathrm{~L} \mathrm{~h} /$ day, ${ }^{(\mathrm{B})}=$ Price/Kw/LE. Depreciation $=$ lighting $\mathrm{h} / \mathrm{Life} s p a n / \mathrm{h}$, price of lamp $/$ LE. L.S. = Life span of the lamp/h. Total Costs $=\mathrm{A}+\mathrm{B} / \mathrm{LE}$.

Also, the results of Ahmed et al. (2015) revealed that the use of a 26-watt saving lamps minimized the lighting costs by about $56.20 \%$, while the $60 \mathrm{~cm}$ fluorescent lamp 40 watt decreased the lighting costs by about $34.53 \%$ as compared to the incandescent lamp 60 watt.

\section{Conclusion}

Light sources should be suitable for commercial poultry facilities to reduce energy cost and obtain optimum production efficiency. Therefore, it could be concluded that using of light emitting diodes lamps is highly recommended in the broiler production to achieve the best possible profit, especially with the progressive increase in the prices of feed ingredients and power cost.

\section{References}

Ahmed, S. F., El-Hammady, H. Y., Farghly, M. F. A. and Madian, A. H. (2015), "Impact of some light sources on growth performance and sexual maturity of female Japanese quail", Assiut Journal of Agricultural Sciences, Vol. 46, pp.135-147.

Angélica, S. M., Paixão, S. J., Restelatto, R., Morello, G. M., Moura, D. J. d. and Possenti, J. C. (2013), "Performance and preference of broiler chickens exposed to different lighting sources", The Journal of Applied Poultry Research, Vol. 22, pp. 62-70.

Behnke, K. C. and Beyer, R. S. (2002), Effect of feed processing on broiler performance, VIII. International 
Seminar on Poultry Production and Pathology, Santiago, Chile.

Bertolucci, C. and Foa, A. (2004), "Extraocular photoreception and circadian entrainment in nonmammalian vertebrates", The Journal of Biological and Medical Rhythm Research, Vol. 21, pp. 501519.

Blair, R., Newberry, R. C. and Gardiner, E. E. (2000), "Effects of lighting pattern: Broiler house lighting sources and photoperiods" Poultry Science, Vol. 69, pp. 1471-1479.

Cao, J., Liu, W., Wang, Z., Xie, D., Jia, L. and Chen, Y. (2008), "Green and blue monochromatic lights promote growth and development of broilers via stimulating testosterone secretion and myofiber growth", Journal of Applied Poultry Research, Vol. 17, pp. 211-218.

Deep, A., Schwean-Lardner, K., Crowe, T. G., Fancher, B. I. and Classen, H. L. (2010), "Effect of light intensity on broiler production, processing characteristics, and welfare", Poultry Science, Vol. 89, pp. 2326-2333.

Duncan, D. B. (1955), "Multiple range and multiple F-tests. Biometrics", Vol. 11, pp. 1-42.

El-Hammady, H. Y., El-Sagheer, M., Hassanien, H. H. M. and Hassan, H. A. (2014), Impact of light source and feed form on growth performance and carcass traits of broiler chicks, The $7^{\text {th }}$ International Poultry Conference, Egypt, ID10029.

Farghly, M. F. A and Abdelnabi, M. A. (2011), "Using saving light bulbs as economical alternative light source for raising Dandarawi chicken", Egyptian Journal of Animal Production, Vol. 48, pp. 335-351.

Farghly M. F. A., Metwally, M. A., Abdelnabi, M. A. and Sharaqa, T. M. (2015a), Effect of light source and type on growth performance of sharkasi chickens, Fifteenth Scientific Conference of the Egyptian Society for Nutrition and Feeds, Egypt.

Farghly M. F. A., El-Hammady, H. Y, Madian, A. H. and Ahmed, S. F. (2015b), Productive and reproductive performance of Japanese quail affected by light source, Fifteenth Scientific Conference of the Egyptian Society for Nutrition and Feeds, Egypt.

Hakan, B. and Ali, A. (2005), "Effects of light wavelength on broiler performance", Hayvansal Üretim, Vol. 46 pp.22-32.

Halevy, O., Biran I., and Rozenboim, I. (1998), "Various light source treatments affect body and skeletal muscle growth by affecting skeletal muscle satellite cell proliferation in broiler", Comparative Biochemistry and Physiology Part A: Molecular \& Integrative Physiology, Vol. 120, 
pp. $317-323$.

Hamdy, A. H. (2014), Some managerial manipulations for improving egg and meat production in chickens, Ph.D. thesis, Department of Poultry Production, Faculty of Agriculture, South Valley University, Egypt.

Hossein, S. and Zaghari, M. (2016), "Effect of light emitting diodes with different color temperatures on immune responses and growth performance of male broiler", Animal. Science, Vol. 17 No. 2, pp. 545-553.

Huth, J. C. and Archer, G. S. (2015), "Comparison of two LED light bulbs to a dimmable CFL and their effects on broiler chicken growth, stress, and fear", Poultry Science, Vol. 94, pp. 2027-2036.

Kristensen, H. H., Perry, G. C., Prescott, N. B., Ladewig, J., Ersbøll, A. K. and Wathes, C. M. (2006), "Leg health and performance of broiler chickens reared in different light environments", British Poultry Science, Vol. 47, pp. 257-263.

Lewis, P. D., Perry, G. C. and Morris, T. R. (2003), "Effect of two opposing changes in photoperiod upon age at first egg and related traits in layerhybrid pullets", The Journal of Agricultural Science, Vol. 140, pp. 373-380.

Li, J., Cao. J., Wang, Z., Dong, Y. and Chen, Y. (2015), "Melatonin plays a critical role in inducing $B$ lymphocyte proliferation of the bursa of Fabricius in broilers via monochromatic lights", Journal of Photochemistry and Photobiology B: Biology, Vol. 142, pp. 29-34.

Lien, R. J., Hess, J. B., McKee, S. R., Bilgili, S. F. and Townsend, J. C. (2007), "Effect of light intensity and photoperiod on live performance, heterophil-to-lymphocyte ratio, and processing yields of broilers intensity and photoperiod on live performance heterophil-tolymphocyte ratio, and processing yields of broilers", Poultry Science, Vol. 86 pp. 1287-1293.

Lien, R. J., Hess, J. B., McKee, S. R. and Bilgili, S. F. (2008), "Effect of light intensity on live performance and processing characteristics of broilers", Poultry Science, Vol. 87, pp. 853-857.

Long, S. (1982), "Acid-base balance and urinary acidification in birds", Comparative Biochemistry and Physiology Part A: Physiology, Vol. 71, pp. 519-526.

Mendes, A. S., Paixão, S. J., Restelatto, R., Morello, G. M., de Moura, D. J. and Possenti, J. C. (2013), "Performance and preference of broiler chickens exposed to different lighting sources", The Journal of Applied Poultry Research, Vol. 22, pp. 62-70.

Mohamed, R. A., El-Kholya, S. Z., 
Shukry, M., El-Kassas, S. and ElSaidy, N. R. (2017), "Manipulation of broiler growth performance, physiological and fear responses using three monochromatic LED lights", Alexandria Journal of Veterinary Sciences, Vol. 53, pp. 57-56.

Moore, C. B and Siopes, T. D. (2003), "Melatonin enhances cellular and humoral immune responses in the Japanese quail (Coturnix coturnix japonica) via an opiatergic mechanism", General and Comparative Endocrinology, Vol. 131, pp. 258-263.

North, M. O and Bell, D. D. (1990), Commercial chicken production manual, $4^{\text {th }}$ Edition, Springer, New York, USA.

Olanrewaju, H. A., Miller, W. W., Maslin, W. R., Collier, S. D., Purswell, J. L. and Branton, S. L. (2016), "Effects of light sources and intensity on broilers grown to heavy weights. Part 1: "Growth performance, carcass characteristics and welfare indices", Poultry Science, Vol. 95, pp. 727-735.

Olanrewaju, H. A., Purswell, J. L., Maslin, W. R., Collier, S. D. and Branton, S. L. (2015), "Effects of color temperatures (kelvin) of LED bulbs on growth performance, carcass characteristics, and ocular development indices of broilers grown to heavy weights", Poultry science, Vol. 94, pp. 338-344.
Prescott N. B and Wathes, C. M. (1999), "Reflective properties of domestic fowl (Gallus g. domesticus), the fabric of their housing and the characteristics of the light environment in environmentally controlled poultry houses", British Poultry Science, Vol. 40, pp. 185193

Riber, A. B. (2015), "Effects of color of light on preferences, performance, and welfare in broilers", Poultry Science, Vol. 94, pp. 1767-1775.

Rozenboim, I., Biran, I., Uni, Z., Robinzon, B. and Halevy, O. (1999), "The effect of mono-chromatic light on broiler growth and development", Poultry Science, Vol. 78, pp. 135138.

Rozenboim, I., Piestun, Y., Mo-barkey, N., Barak, M., Hoyzman, A. and Halevy, O. (2004), "Monochromatic light stimuli during embryogenesis enhance embryo development and posthatch growth", Poultry Science, Vol. 83, pp. 14131419.

SAS Institute (2009), SAS/STAT 9.2 User's Guide: Survival Analysis, SAS Institute Inc., Cary, North Carolina, USA.

Simsek, U. G., Bestami, D., Mehmet, C., Ibrahim, H. C. and Muammer, B. (2009), "Effects of enriched housing design on broiler performance, welfare, chicken meat composition and serum cholesterol", Acta 
Veterinary Brno, Vol.78, pp. 67-74.

Wyse, C. and Hazlerigg, D. (2009), "Seasonal biology: Avian photoreception goes deep", Current Biology, Vol. 19, pp. 685-687.

Xie, D., Wang, Z. X., Dong, Y. L., Cao, J., Wang, J. F., Chen, J. L., and Chen, Y. X. (2008), "Effect of monochromatic light on immune response of broilers", Poultry Science, Vol. 87, pp. 1535-1539. 